\title{
Preliminary Study on Effect of Early Defoliation on Dry Matter Accumulation and Storage of Reserves on 'Abbé Fétel' Pear Trees
}

\author{
Karen Mesa \\ Dipartimento di Scienze Agrarie, Alma Mater Studiorum, Università di \\ Bologna, Viale Giuseppe Fanin, 40/50, 40127 Bologna BO, Italy; and \\ Instituto de Ciencias Agronómicas y Veterinarias, Universidad de O'Higgins, \\ Avenida Libertador Bernardo O'Higgins 611, 2841959, Rancagua, Chile
}

\section{Sara Serra \\ Tree Fruit Research and Extension Center, Washington State University, 1100 N. Western Avenue, Wenatchee, WA 98801; and Department of Horticulture, Washington State University, 149 Johnson Hall, P.O. Box 646414, Pullman, WA 99164-6414

\begin{abstract}
Andrea Masia, Federico Gagliardi, and Daniele Bucci Bologna, Viale Giuseppe Fanin, 40/50, 40127 Bologna BO, Italy
\end{abstract} \\ Dipartimento di Scienze Agrarie, Alma Mater Studiorum, Università di \\ Stefano Musacchi \\ Tree Fruit Research and Extension Center, Washington State University, 1100 N. Western Avenue, Wenatchee, WA 98801; and Department of Horticulture, Washington State University, 149 Johnson Hall, P.O. Box 646414, Pullman, WA 99164-6414}

Additional index words. crop-load, dormancy stage, Pyrus communis, soluble carbohydrates, starch

\begin{abstract}
Annual accumulation of starch is affected by carbon reserves stored in the organs during the growing season and is controlled mainly by sink strength gradients within the tree. However, unfavorable environmental conditions (e.g., hail events) or application of management practices (e.g., defoliation to enhance overcolor in bicolor apple) could influence the allocation of storage carbohydrates. This preliminary research was conducted to determine the effects of early defoliation on the dry matter, starch, and soluble carbohydrate dynamics in woody organs, roots, and mixed buds classified by age and two levels of crop-load for one growing season in 'Abbé Fétel' pear trees (Oct. 2012 to mid-Jan. 2013 in the northern hemisphere). Regardless of the organs evaluated (woody organs, roots, and mixed buds), an increase of soluble carbohydrate concentration was observed in these organs in the period between after harvest (October) and January (dormancy period). Among all organs, woody short-old spurs showed the highest increase $(+93.5 \%)$ in soluble sugars. With respect to starch, woody organs showed a clear trend of decreasing in concentration between October and January. In this case, short-old spurs showed the smallest decline in starch concentrations, only $6.5 \%$, whereas in other tree organs starch decreased by $34.5 \%$. After harvest (October), leaves showed substantially higher starch and soluble sugar concentrations in trees with lower croploads. These results confirm that in the period between October and January, dynamic interconversions between starch and soluble carbohydrates occur at varying magnitudes among organs in pear trees.
\end{abstract}

Annual accumulation, mobilization, and allocation of carbohydrates in fruit trees among individual organs is greatly affected by the availability of stored carbon reserves, assimilates from photosynthesis, and cropload within a tree (Keller and Loescher, 1989; Monerri et al., 2011). Ultimately, the final accumulation of carbohydrates in tree organs is determined by their sink strength (Ho, 1988). Storage carbohydrates sustain the early stages of growth in spring, during budbreak and leaf growth until leaves have developed the photosynthetic capacity to independently support net carbon assimilation (Flore and Layne, 1999; Regier et al., 2010; Whiley et al., 1996a). During the dormant period (fall-winter), hydrolysis of starch and storage proteins occurs (Grochowska, 1973; Titus and Kang, 1982), supporting bud development (Keller and Loescher, 1989; Loescher et al., 1990) in the form of nucleic acid and protein synthesis (Zimmerman et al., 1970).
Abbott (1970) postulated that apple buds continue developing during the entirety of the winter dormancy period. The magnitude of such bud development occurring after leaf fall depends on the ability of the tissue to generate energy (Abbott, 1970) via the availability of storage carbohydrates (starch) that enable the synthesis of nucleic acids and storage proteins (Faust, 1989); however, not all cultivars are able to use this alternate respiratory pathway during winter to develop buds. These cultivars normally present a longer spring heating requirement to initiate budbreak (Faust, 1989). Similarly, chilling hour accumulation (Richardson et al., 1974; Weinberger, 1950 ) is a key factor for the duration of the latency period and is also species- and cultivardependent (Ito et al., 2012; Marafon et al., 2011). In these aspects, starch acts as the main insoluble carbohydrate stored during the previous summer and autumn and is responsible for the fulfillment of metabolic functions during dormancy and the following spring (Regier et al., 2010).

It has been indicated that the roots and shoots are the main organs that compete for available assimilates during tree growth, although shoots are generally thought to have priority over roots (Flore and Layne, 1999). Chalmers and Van den Ende (1975) proposed that in small-young (nonfruiting) peach trees, assimilates are partitioned mainly to support vegetative and structural growth (tree frame and roots), whereas in large-mature fruiting trees, the most substantial percentage of assimilates is allocated to the fruit. Hansen (1967) stated that reserves partitioning among shoots, trunk, and roots depends on the growth intensity (strength) and activity of each organ. This concept of "sink strength" is defined as the power of an organ or tissue to import assimilates and varies mainly with species, tree vigor, and tree age (Kozlowski, 1992; Marquat et al., 1999). Moreover, sink strength among organs varies with seasonal development patterns of a tree, as well as over time (Flore and Layne, 1999).

Wünsche et al. (1996) showed that total dry matter accumulation and tree yield efficiency [kilogram of fruit produced by a tree per trunk cross-sectional area (TCSA) in centimeters squared] are related to the total light interception by the orchard up to harvest. It also has been reported that the accumulation of dry matter in one growing season could be influenced by the crop-load, whereby apple trees with a high crop-load reported larger concentrations in comparison with trees without fruit or with very low cropload (Faust, 1989; Hansen, 1971). Hansen (1973) later demonstrated that fruit removal reduced carbohydrate translocation from the surrounding leaves within 24 to $48 \mathrm{~h}$ after the sink (fruit) was detached. This result is in accordance with Wünsche et al. (1996), who claimed that leaves of fruiting trees are more photosynthetically efficient than those of nonfruiting trees. Hansen (1982) demonstrated that when the area of leaves nearest to a fruit (photosynthetically active leaves supporting one fruit) increased from 200 to 
$800 \mathrm{~cm}^{2}$, the net tree assimilation rate decreased $\approx 40 \%$ and leaves began accumulating starch. Hansen and Stoyanov (1972) recommended an area of leaves $\approx 200 \mathrm{~cm}^{2}$ as necessary to support the growth of $100 \mathrm{~g}$ of fresh apple weight.

Alternate bearing is a phenomenon that affects both deciduous and evergreen trees. In avocado (Scholefield et al., 1985; Whiley et al., 1996a, 1996b), pistachio (Nzima et al., 1997), and citrus (Goldschmidt and Golomb, 1982), the likelihood of showing alternate bearing tendency appears to be closely related to the amount of carbohydrates stored between the postharvest period and before the dormancy break. It has been suggested that unfavorable growing conditions, such as severe water stress (Loescher et al., 1990; Lopez et al., 2007), or management practices, such as a high crop-load in the previous season (Park, 2011), could affect the accumulation of carbohydrate reserves in roots, and thereby affect the yield in the following season as a result of a decrease in available assimilates. Whiley et al. (1996b) stated that the accumulation of carbohydrate reserves in avocado trees would be larger in a year of low crop-load in comparison with a high crop-load year, and as a consequence high yields would be obtained because of greater availability of assimilates accumulated during the previous year.

The performance of future cropping is affected mainly by alteration of assimilate reserves in the tree caused by abiotic and biotic stress at the end of the season as well as management practices that increase light penetration (Loescher et al., 1990; Kozlowski, 1992). Palmer (1999), Robinson and Lakso (1991), and Wünsche et al. (1996) stated that there is a positive relationship between dry matter production and the total amount of solar radiation intercepted by the orchard. Moreover, Robinson and Lakso (1991) pointed out that these two variables depend on factors such as canopy characteristics and their spacing. Rom (1991) described the importance of light on different physiolog-

Received for publication 7 Aug. 2019. Accepted for publication 23 Sept. 2019.

This research was funded by AGER (Agroalimentare e Ricerca-Fondazione Cariplo), project number: 2010-2017. Any opinions, finding, or recommendations expressed in this publication are those of the author(s) and do not necessary reflect the view of AGER. This work was also supported by the U.S. Department of Agriculture National Institute of Food and Agriculture Hatch project 1014919, Crop Improvement and Sustainable Production Systems (WSU reference 00011). K.M. thanks CONICYT, BCH/Doctorado-No. 72110476, for financial support. We thank Alexander Goke for his critical editing contribution and accurate revision of the manuscript.

This article is part of K.M.'s $\mathrm{PhD}$ dissertation entitled "Starch distribution in pear tree organs in relation to training systems, rootstocks, and fruit quality," from the Department of Scienze Agrarie, University of Bologna, delivered in May 2015.

S.M. is the corresponding author. E-mail: stefano. musacchi@wsu.edu. ical and morphological aspects, as well as its influence on management practices, such as pruning. Chalmers and Van den Ende (1975) suggested that the age or size at which the tree optimizes dry matter partitioning to fruit may change with orchard design or management. Cruz-Castillo et al. (2010) demonstrated in kiwifruit that by reducing vigor and exposing leaves and fruits to sunlight by early defoliation 5 days after full bloom and throughout the season can cause a poor return bloom the following year because of the rapid depletion of nonstructural carbohydrates in the previous summer. Adverse environmental factors (e.g., hailstorm or high temperature and humidity often in tropical and subtropical regions) could produce bacterial and fungal disease resulting in early natural defoliation as Lloyd and Firth (1990) reported for peach trees. Early defoliation (34 weeks before harvest) is also becoming more spread in bicolor apple genotypes to improve the percentage of overcolored surface of the fruits. Specialized orchard equipment made in Europe can perform tree defoliation in a fast way using an air compressor jet stream. Loescher et al. (1990) noted that treatments like defoliation or pruning performed in the orchard affect mainly roots in terms of depletion of stored carbohydrates. In one of the first studies on carbohydrate reserve dynamics in pear trees, Cameron (1923) indicated that nonpruned trees began to store starch earlier than the pruned trees because of a major presence of young spurs. Further, summer pruning practice may redirect the distribution of carbohydrates to fruit as a consequence of the removal of vegetative sinks (Loescher et al., 1990). In this way, all orchard practices aiming to maintain an optimal leaf area and delay leaf senescence could allow a greater carbohydrate assimilation after harvest, resulting in a sufficient/optimal accumulation of carbohydrate reserves to support initial growth and development in the following season (Kozlowski, 1992; Tustin et al., 1997).

In the present work, we evaluated starch and soluble sugar dynamics in relation to cropload in 'Abbé Fétel' pear trees. In addition, we manipulated the reserve accumulation by an early defoliation (October) of the tree after harvest to investigate the effect of this practice on dry matter, starch, and soluble carbohydrates in woody organs, roots, and mixed buds. This research provides preliminary results to understand the effect of leaf removal on carbohydrate reserve accumulation across woody organs.

\section{Materials and Methods}

\section{Plant material}

This study was conducted during one growing season (from Oct. 2012 to Jan. 2013) in an orchard established in 1997 of 'Abbé Fétel' (Pyrus communis L.) grafted on Quince MC (Cydonia oblonga Mill.) rootstock and trained as spindle at a planting density of $3.6 \mathrm{~m} \times$ $0.7 \mathrm{~m}$. Quince MC is one of the most dwarfing rootstocks available to control vigor in high-density pear orchards (Musacchi, 2011; Sansavini et al., 2008). The orchard (north-south oriented) was located at the Experimental Station of University of Bologna, Faculty of Agriculture, in Cadriano, Italy (lat. $44^{\circ} 54^{\prime} 88.53^{\prime \prime} \mathrm{S}$, long. $11^{\circ} 38^{\prime} 59.30^{\prime \prime} \mathrm{W}$ ). Cultural practices were standardized according to those used in commercial orchards of 'Abbé Fétel' grafted on quince rootstocks.

Experimental design and sampling. A total of 12 homogeneous trees in size and vigor (average TCSA $60.2 \pm 1.5 \mathrm{~cm}^{2}$ ) were selected during July 2012 within the orchard for this experimental trial. According to crop-load evaluated at harvest on 17 Sept. 2012, two levels were present for further tree categorization corresponding to medium crop-load (MCL) with an average of 25 pears per tree and 0.41 fruits $/ \mathrm{cm}^{2}$ TCSA, and low crop-load (LCL) with an average of 10 pears per tree and 0.16 fruits $/ \mathrm{cm}^{2}$ TCSA (Supplemental Table 1). A high crop-load level was not selected because it was absent in the orchard that year. In general, the orchard presented a quite low level of crop due to unfavorable weather conditions during bloom. For each level of crop-load, six trees were destructively evaluated, three of them after harvest of the 2012 season (9 Oct. 2012) with an average of $0.27 \pm 0.06$ fruits $/ \mathrm{cm}^{2}$ TCSA, and the others in January (14 Jan. 2013) with an average of $0.31 \pm 0.09$ fruits $/ \mathrm{cm}^{2}$ TCSA.

In each crop-load level (medium and low) three of the six trees were defoliated by hand before natural abscission (October) and three followed a natural defoliation during fallwinter (26 Nov. 2012).

In the 12 trees under investigation, we determined the fresh weight (FW) and dry weight (DW), starch, and carbohydrate concentrations of the different organs: wood, mixed buds, roots, and leaves. We also considered the growing degree days and chilling unit accumulation (Anderson et al., 1986; Richardson et al., 1974) (Table 1).

Trees were carefully dug out beneath the main root system (100-cm depth) using a trencher-equipped tractor at each time of sampling. Aboveground tree organs were fractioned into the following components: leaves (when present), 1-year-old branches (brindle-type shoots, mixed and vegetative buds, and vegetative shoots as 1-year shoots "mixed shoots"), 2-year-old branches, 3-yearold branches, 4+-year-old branches, short-old spurs, trunk (aboveground stem starting at the grafting point), and mixed buds. The mixed buds (buds containing both flower and leaf primordia are present) were sampled from each structure when they were present, and these were removed without including the portion of the spur to which they belonged. Vegetative buds at the time of destruction were considered as part of the holding wood structure where they belonged (no separation was made). Below-ground organs (below the grafting point) were divided into root stump, coarse roots (thickness $>2 \mathrm{~mm}$ ), and fine roots (thickness $<2 \mathrm{~mm}$ ) (Silver and Miya, 2001; Zhang and Wang, 2015). Ages of the tissues 
Table 1. Dates of sampling (2012-13) for different tree organs: wood, mixed buds, roots, and leaves. Tree organ samples were collected for further starch and soluble carbohydrate quantifications. Pears were harvested on 17 Sept. 2012 for all the experimental trees in trial.

\begin{tabular}{lccc}
\hline & \multicolumn{2}{c}{ 2012-13 } & Natural Leaf \\
\cline { 2 - 4 } Sampling day for/Treatment & $\begin{array}{c}\text { After Harvest } \\
\text { (October) }\end{array}$ & $\begin{array}{c}\text { Wall (November) } \\
\text { (January) }\end{array}$ & 14 Jan. 2013 \\
\hline Wood organs, mixed buds, and roots & 9 Oct. 2012 & - & - \\
Leaves & 9 Oct. 2012 & 26 Nov. 2012 & 2,312 GDD \\
$\begin{array}{l}\text { GDD (natural fall leaves) } \\
\begin{array}{l}\text { CU accumulation (at sampling } \\
\quad \text { date on January) }\end{array}\end{array}$ & & CU \\
\hline
\end{tabular}

GDD = growing degree days; $\mathrm{CU}=$ chilling unit.

refer to their physiological ages at the beginning of each season (e.g., 1-year shoots developed in the season 2011-12).

Dry matter partitioning. Immediately after tree destruction and organ partitioning, FW was measured for all components. Roots were rinsed with tap water to remove soil debris and left in the open air for $40 \mathrm{~min}$ before FW determinations. Randomly selected representative tissue subsamples were weighed then dried in a forced-air oven at $60{ }^{\circ} \mathrm{C}$ until constant mass to determine DW. Dry matter (\%) was calculated as $(\mathrm{DW} / \mathrm{FW}) \times$ 100 (Palmer, 1988, 1992).

Leaf measurements. Leaf measurements were carried out at two different times of the experiment: the first sampling took place in October (22 d after harvest), and the second during natural leaf abscission (late November, Table 1). The total number of leaves was counted for each of three LCL and three MCL trees. At the October sampling, the total number of leaves was obtained by manually removing and counting all leaves in the canopy. Meanwhile, chosen trees for the late November leaves sampling were enclosed in a white net bag (material similar to nets used for hail protection) to collect leaves that otherwise would have fallen on the ground and dispersed. Leaves were harvested at four intervals from each net between 19 Oct. 2012 and natural leaf fall. The remaining leaves still attached to the trees (average of 5\%) were manually harvested at the last sampling (end of November). At each partial sampling date, the number and total weight of leaves collected from the net were determined. Leaf area (LA, in centimeters squared) was determined with a leaf area meter (LI-3100; LICOR, Lincoln, NE) on a subsample of leaves from each tree corresponding to $20 \%$ of total leaf weight/tree/sampling time. Total LA was then estimated by multiplying the number of leaves by the average LA obtained from the $20 \%$ subsample. Leaf Area Index (LAI) was calculated as total LA of the tree divided by ground area occupied by the tree (Rom, 1991; Wünsche and Lakso, 2000).

\section{Nonstructural carbohydrate determination}

Material preparation. From the two sampled dates for wood, roots, and mixed buds (Oct. 2012 and Jan. 2013) and for leaves (Oct. 2012 and Nov. 2012, Table 1), a subsample of $50 \mathrm{~g} \mathrm{FW}$ of each organ was used for starch and soluble carbohydrate analysis. For the mixed buds, two-thirds of the total weight of samples was used for quantifications. Subsamples were immediately frozen in liquid nitrogen and stored at $-80{ }^{\circ} \mathrm{C}$ until analyses. Successively, samples were kept for $7 \mathrm{~d}$ in a freeze dryer (HETO drywinner; DW3, Allerød, Denmark), then reweighed and, once weights were stable, ground to a fine powder with a mill (Pulverisette 14; Fritsch GmbH, Idar-Oberstein, Germany) and stored in airtight containers at room temperature. All organs (except mixed buds), were ground first with a $0.25-\mathrm{mm} \varnothing$ sieve, and subsequently with a $0.20-\mathrm{mm} \varnothing$ sieve using a mill. Mixed buds were directly ground in a $0.20-\mathrm{mm} \varnothing$ sieve mill.

Determination of soluble carbohydrates and starch concentrations. For the following analysis, three technical replicates of 100-mg DW of each organ were used. Extraction and analysis of carbohydrate concentrations followed the protocol initially described by Roe (1955) and later used on pear organs and tissues by Mesa et al. (2016) with modifications.

Total soluble carbohydrates were extracted three times by $5 \mathrm{~mL}$ of methanol:chloroform: water solvent $(12: 5: 3, \mathrm{v} / \mathrm{v} / \mathrm{v})$, and allowed to work for $30 \mathrm{~min}$. Samples were then centrifuged for $10 \mathrm{~min}$ at $5000 \mathrm{~g}_{\mathrm{n}}$ and the three resulting supernatants were collected, pooled, and evaporated in a rotary evaporator (HeiVAP value/G3; Heidolph, Schwabach, Germany) at $60{ }^{\circ} \mathrm{C}, 100 \mathrm{rpm}$ until organic molecules were totally evaporated. The aqueous residue was then brought to a volume of $10 \mathrm{~mL}$ with distilled water. To remove interfering phenolic compounds, $0.2 \mathrm{~g}$ polyvinylpolypyrrolidone (Sigma Aldrich, St. Louis, MO) was added in each sample, shaken, and then centrifuged.

The total insoluble residue was obtained after the extraction process of the soluble phase. This process was executed in three main steps as reported by Mesa et al. (2016). First, $2 \mathrm{~mL}$ of distilled water was added to be subsequently autoclaved. Then, $1 \mathrm{mg}$ amyloglucosidase from Aspergillus niger was added for the enzymatical digestion. The samples rested at room temperature for $18 \mathrm{~h}$, then centrifuged at $5000 g_{\mathrm{n}}$ three times, and the supernatants pooled and brought to a final volume of $10 \mathrm{~mL}$ with distilled water.

Spectrophotometer analysis. Spectrophotometer determination of carbohydrate content was performed as previously described by Mesa et al. (2016). The subsample was composed of $1 \mathrm{~mL}$ aliquot of the sample plus $10 \mathrm{~mL}$ of anthrone reagent. Subsequently, samples were boiled in water and then cooled to room temperature. The analysis was performed by reading the absorbance by spectrophotometer (VIS-ultraviolet Varian model Cary 1E; Varian, Inc., Palo Alto, CA) at $620 \mathrm{~nm}$. Nonstructural carbohydrate concentrations were reported as glucose equivalents (milligrams per gram of DW of tissue) and corrected for the appropriate dilutions. Starch concentration was also multiplied by 0.9 to account for the mass of glucose theoretically hydrolyzed from a unit mass of starch (Seager and Haslemore, 1993; Smith and Zeeman, 2006).

\section{Statistical analysis}

The experiment was arranged as a completely randomized design with 12 trees as experimental units and two factors with two levels each $(2 \times 2)$ : two crop-loads and two dates of sampling for leaf measurements. Three replicates were used for each date of sampling and crop-load level $(2$ dates $\times 2$ crop-load levels $\times 3$ trees/crop-load $/$ date $=12$ trees total). In the case of woody organs, roots, and mixed buds, only the date of sampling was considered as factor (not the crop-load), and for each treatment six replicates were used. All data collected were statistically analyzed with R software version 3.4.3 (R Core Team, 2017) using analysis of variance followed by Student-NewmanKeuls means separation. Differences in pairwise comparisons were considered significant at $P \leq 0.05$.

\section{Results}

\section{FW and DW analysis}

MCL trees of 'Abbé Fétel' pear trees evaluated in 2012 showed values for yield $\approx 2.5$ times higher than those in LCL trees (Supplemental Table 1).

Woody organs, roots, and mixed buds. FW measurements for the different tissues showed no significant differences between sampling dates for the woody organs, mixed buds, and roots (Table 2). Mixed buds and 2-year-old branches exhibit a tendency of greater FW in January, although mean values were not statistically significant. Mixed bud FW corresponded to a significant $20 \%$ increase (Fig. 1). October treatment registered the highest number of mixed buds (619), although it did not differ statistically from the January treatment.

At the sampling date in October, the two levels of crop-load established (MCL and LCL) showed significant differences in terms of DW (g) only for the structure of 2-yearold (wood) branches (data not shown). The 2-year-old branches sampled from LCL trees obtained a $66.3 \%$ higher value for DW $(\mathrm{g})$ in comparison with MCL trees. For all other sampled organs, no statistically significant differences were found (data not shown).

A comparison between dates of sampling for DW (g) showed significant differences only for coarse roots (Supplemental Table 2). Mixed buds, 3-year-old branches, 4+-yearold branches, short-old spurs, trunk, and coarse and fine roots presented the same trend 
Table 2. Total fresh weight of each organ sampled per tree: woody organs, roots, and mixed buds evaluated at different dates.

\begin{tabular}{|c|c|c|c|c|}
\hline \multirow[b]{2}{*}{ Organs } & \multicolumn{4}{|c|}{ Fresh wt } \\
\hline & Unit & October & January & Significance $^{2}$ \\
\hline \multicolumn{5}{|l|}{ Wood } \\
\hline 1-year & $\mathrm{g}$ & 534.0 & 528.7 & NS \\
\hline 2-year & $\mathrm{g}$ & 357.8 & 415.4 & NS \\
\hline 3 -year & $\mathrm{g}$ & 365.2 & 282.8 & NS \\
\hline 4 -year & $\mathrm{kg}$ & 3.4 & 3.0 & NS \\
\hline Spurs & $\mathrm{g}$ & 305.3 & 197.1 & NS \\
\hline Trunk & $\mathrm{kg}$ & 8.0 & 8.9 & NS \\
\hline Mixed buds & $\mathrm{g}$ & 48.0 & 60.0 & NS \\
\hline & & & & NS \\
\hline Total aboveground & $\mathrm{kg}$ & 13.0 & 13.4 & NS \\
\hline \multicolumn{5}{|l|}{ Roots } \\
\hline Coarse (>2 mm) & $\mathrm{kg}$ & 2.2 & 1.7 & NS \\
\hline Fine $(<2 \mathrm{~mm})$ & $\mathrm{g}$ & 111.0 & 107.1 & NS \\
\hline Root stump & $\mathrm{kg}$ & 1.7 & 1.8 & NS \\
\hline Total below ground & $\mathrm{kg}$ & 4.0 & 3.7 & NS \\
\hline Whole tree & $\mathrm{kg}$ & 17.0 & 17.1 & NS \\
\hline
\end{tabular}

These values (means of six replicates) are obtained from the complete destruction of the trees. Lower case letters indicate significant differences among means along rows.

${ }^{\mathrm{z}_{\mathrm{NS}}}$ indicates no significance; Student-Newman-Keuls test was used for mean comparisons.

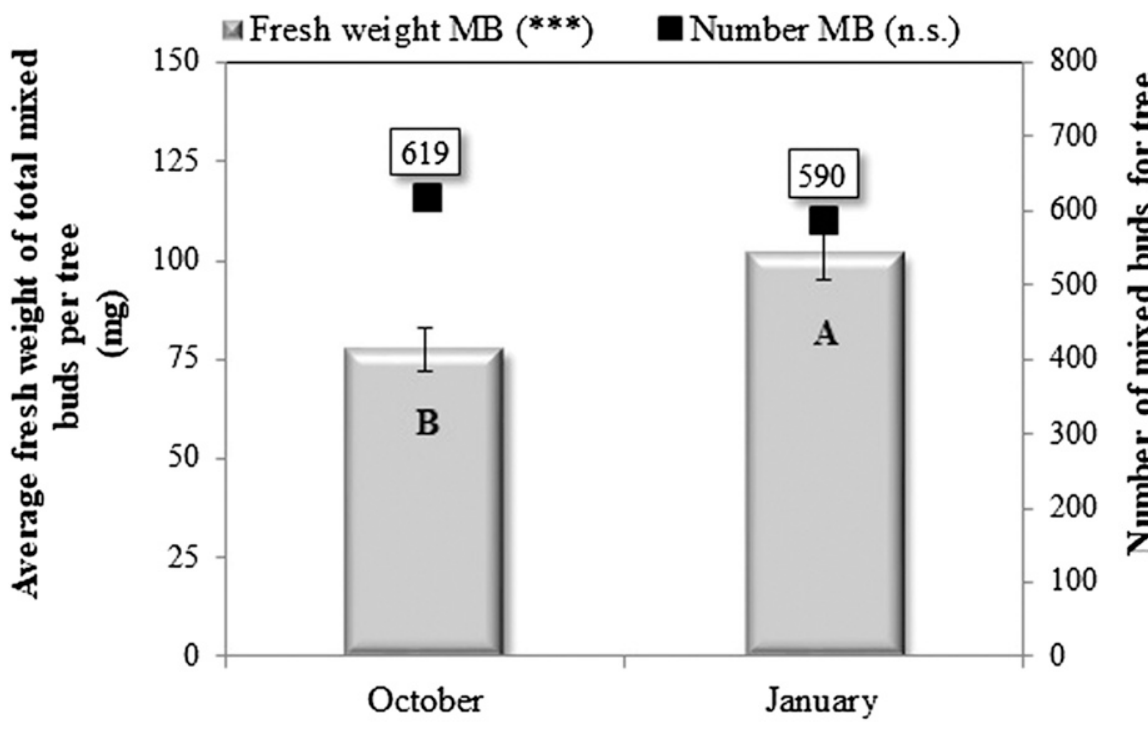

Sampling date

Fig. 1. Average fresh weight (gray bars) and number (black squares) of mixed buds (MB) at different sampling dates. Mean values \pm SE. Upper case letters indicate significant difference in means between sampling dates for average fresh weight. n.s., ${ }^{* *}$ indicate no significance or significance at $P<0.001$, respectively; Student-Newman-Keuls test was used for mean comparisons.

observed by FW (Supplemental Table 2), where organs sampled in October showed the highest values.

Leaf measurements. Crop-loads showed an effect on total leaf number, total leaf weight, LA, and LAI, where MCL presented the highest values for these parameters (Table 3 ). Regarding the comparison between dates of sampling, October vs. natural leaf abscission (late November), the parameters of total leaf weight, average leaf weight, dry matter percentage $(\%$ $\mathrm{DM})$, and percentage of leaf water content ( $\%$ WC) were significantly different (Table 3 ). For total leaf weight, the value recorded in October was higher $(1.67 \mathrm{~kg} /$ tree $)$ than in late November (1.12 kg/tree). The \% WC and \% DM showed significant differences both for the level of crop-load and sampling date, but not for the interaction between them (Table 3). In this way, leaves sampled from trees with an LCL glucose (Glc)/g DW] (Table 4). Soluble carbohydrates in leaves did not present a significant interaction between crop-load level and date of sampling, unlike what was observed for starch concentration (Table 4). Regarding the interaction between factors evaluated for the starch concentrations, differences were found between trees with different crop-load levels sampled in October (Fig. 2), where leaves from trees with an MCL showed the lowest concentration (12.7 mg starch/g DW), being 53.6\% lower than leaves from trees with an LCL $(27.4 \mathrm{mg}$ starch/g DW) (Fig. 2). At natural leaf abscission (November), the starch concentrations correspond to $28.3 \pm 0.6 \mathrm{mg} \mathrm{starch} / \mathrm{g}$ DW and $29.2 \pm$ $1.2 \mathrm{mg} \mathrm{starch} / \mathrm{g}$ DW for leaves with an MCL and LCL, respectively, without significant statistical differences between them (Fig. 2).

Starch and soluble carbohydrates of woody organs, roots, and mixed buds. The two levels of crop-load identified at harvest (MCL and LCL) did not present significant differences in terms of starch and soluble carbohydrate concentration for the roots and mixed buds evaluated in October (Supplemental Tables 3 and 4). Regarding the different woody organs, starch concentration was significantly different between MCL and LCL only in spurs (higher in MCL) and for soluble carbohydrates in 1- and 3-yearold branches (higher in MCL).

Mixed buds (Fig. 3), roots (Supplemental Fig. 2), or woody organs (Fig. 4) showed a consistent pattern in soluble carbohydrate concentration through the growing season. The concentrations of soluble carbohydrates for the woody structures increased from October to January (Table 5). Among the aboveground woody organs (Table 5), shortold spurs obtained the largest increases between sampling dates, which corresponded to an increase of $93.5 \%$ in $\mathrm{mg}$ Glc/g DW. However, the structures of 2-year-old branches reported only a minor increase between dates $(51.4 \%)$ (Table 5). With respect to mixed buds, nearly a 2-fold increase was recorded from October to January (Fig. 3). This trend was similar for the fine roots, in which changes in carbohydrate concentration differed significantly with an increase of $10.9 \%$ between sampled dates. The coarse roots did not show significant statistical differences between sampling dates (Supplemental Fig. 2).

Regarding starch concentrations, only the woody organs showed a clear trend throughout the growing season. Namely, a decrease occurred between the intervals of each sampling date (Table 6, Fig. 4). Starch concentration in short-old spurs exhibited the smallest decline $(6.5 \%)$ between October and January, whereas the other aboveground structures showed an average decrease of $34.5 \%( \pm 2.0 \% \mathrm{SE})$ for the same period. The starch concentrations in mixed buds and fine roots increased by $21.8 \%$ and $18.0 \%$, respectively, between the two sampling dates (Fig. 3, Supplemental Fig. 2).

With respect to trends among the woody tissues, the greatest variation registered for starch concentration within the 
Table 3. Leaf measurements: number/leaves per tree, total weight per tree, average leaf weight, leaf area/tree, leaf area index (LAI), dry matter percentage (\% DM) and water content percentage (\% WC) regarding the levels of crop-load (CL) in the 2012 season: medium crop-load (MCL) and low crop-load (LCL), and dates of sampling (SD): October and natural leaf fall (November).

\begin{tabular}{|c|c|c|c|c|c|c|c|}
\hline & Leaf number/tree (n) & Total leaf wt/tree $(\mathrm{kg})$ & Avg leaf wt (mg) & Leaf area/tree $\left(\mathrm{m}^{2}\right)$ & LAI & $\% \mathrm{DM}$ & $\% \mathrm{WC}$ \\
\hline \multicolumn{8}{|l|}{ Sampling date (SD) } \\
\hline October & 5,065 & $1.67 \mathrm{a}$ & $333.0 \mathrm{a}$ & 6.48 & 2.57 & $47.4 \mathrm{~b}$ & $52.6 \mathrm{a}$ \\
\hline November & 5,289 & $1.12 \mathrm{~b}$ & $209.2 \mathrm{~b}$ & 6.76 & 2.68 & $70.5 \mathrm{a}$ & $29.5 \mathrm{~b}$ \\
\hline Significance & NS & $* * *$ & $* * *$ & NS & NS & $* * *$ & $* * *$ \\
\hline \multicolumn{8}{|l|}{ Crop-load (CL) } \\
\hline MCL & $5,959 \mathrm{a}$ & $1.59 \mathrm{a}$ & 267.2 & $7.81 \mathrm{a}$ & $3.10 \mathrm{a}$ & $57.6 \mathrm{~b}$ & $42.4 \mathrm{a}$ \\
\hline LCL & $4,395 \mathrm{~b}$ & $1.20 \mathrm{~b}$ & 275.0 & $5.44 \mathrm{~b}$ & $2.16 \mathrm{~b}$ & $60.3 \mathrm{a}$ & $39.7 \mathrm{~b}$ \\
\hline Significance & $* *$ & $* * *$ & NS & $* * *$ & $* * *$ & $*$ & $*$ \\
\hline Interaction $\mathrm{CL} \times \mathrm{SD}$ & NS & NS & $* *$ & NS & NS & NS & NS \\
\hline
\end{tabular}

Values are means of six replicates for each factor. The factorial analysis (interaction CL $\times$ SD) considered three replicates. Lower case letters indicate significan differences among means along rows. NS, ${ }^{*}, * * * * *$ indicate no significance or significance at $P<0.05,0.01$, or 0.001 , respectively; Student-Newman-Keuls test was used for mean comparisons.

Table 4. Leaf soluble carbohydrates [mg Glucose (Glc)/g dry weight (DW)] and starch concentrations (mg starch/g DW) for the two factors evaluated in the 2012 season, sampling dates (SD): after harvest (October) and natural leaf fall, and crop-load (CL): medium (MCL) and low (LCL) level.

\begin{tabular}{|c|c|c|c|c|}
\hline & \multicolumn{2}{|c|}{ Leaf soluble carbohydrates } & \multicolumn{2}{|c|}{ Leaf starch } \\
\hline & \multicolumn{2}{|c|}{ (mg Glc/g DW) } & \multicolumn{2}{|c|}{ (mg starch/g DW) } \\
\hline SD & & & & \\
\hline October & $76.5 \pm 1.9$ & $\mathrm{a}$ & $20.0 \pm 2.1$ & $\mathrm{~b}$ \\
\hline November & $15.6 \pm 1.0$ & $\mathrm{~b}$ & $28.8 \pm 0.7$ & $\mathrm{a}$ \\
\hline Significance & $* * *$ & & $* * *$ & \\
\hline \multicolumn{5}{|l|}{$\mathrm{CL}$} \\
\hline MCL & $42.8 \pm 7.2$ & $\mathrm{~b}$ & $20.5 \pm 1.9$ & $\mathrm{~b}$ \\
\hline LCL & $49.2 \pm 7.8$ & $\mathrm{a}$ & $28.3 \pm 1.1$ & $\mathrm{a}$ \\
\hline Significance & $* * *$ & & $* * *$ & \\
\hline Interaction $\mathrm{CL} \times \mathrm{SD}$ & \multicolumn{2}{|c|}{ NS } & \multicolumn{2}{|c|}{$* * *$} \\
\hline
\end{tabular}

Lower case letters along columns indicate significant difference in means. NS, $* * *$ indicate no significance or significance at $P<0.001$, respectively; Student-Newman-Keuls test was used for mean comparisons.

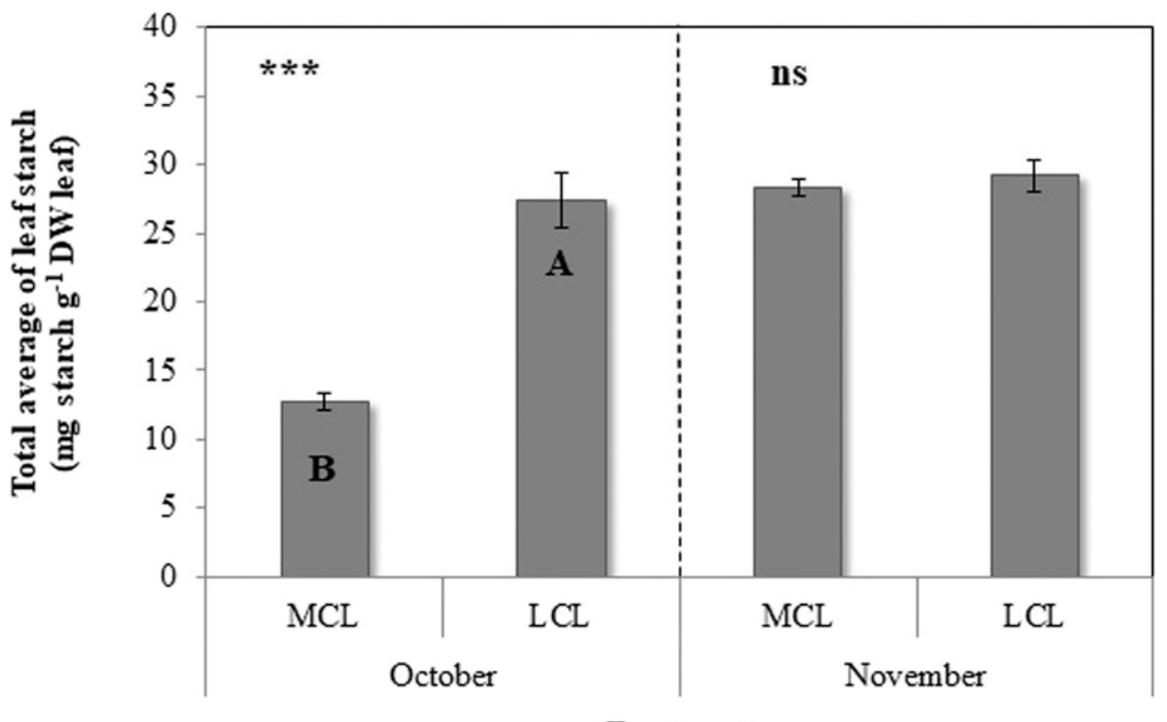

Treatment

Fig. 2. Interaction between factors of crop-load [medium crop-load (MCL) and low crop-load (LCL)] and date of sampling (after harvest and natural leaves fall) for total average of leaf starch concentration [mg starch/g dry weight (DW)]. Mean values \pm SE. Lower case letters indicate significant difference in means. ns, *** indicate no significance or significance at $P<0.001$, respectively; Student-NewmanKeuls test was used for mean comparisons $(\mathrm{n}=3)$.

same evaluation date, ranging from 50.2 to $102.0 \mathrm{mg} \cdot \mathrm{g}^{-1} \mathrm{DW}$ (October) for old short spurs and 2-year-old branches, respectively (Table 6). One-year-old shoots and 2-yearold branches presented the highest starch concentration values in October (Fig. 4). The short-old spurs presented the highest values of soluble carbohydrate concentrations,
$35.6 \mathrm{mg} \cdot \mathrm{g}^{-1} \mathrm{DW}$ in October and $68.9 \mathrm{mg} \cdot \mathrm{g}^{-1}$ DW in January, respectively (Fig. 4).

\section{Discussion}

\section{FW and DW analysis}

In the mixed buds, the significantly increased average FW between October and
January (Fig. 1) could be explained by the corresponding increase in soluble carbohydrate concentration (Fig. 3). This observation aligns with Marquat et al. (1999), who noted the important absorption potential of sucrose and sorbitol in the stems and buds of peach trees (10-year-old) in October, just before the temperature fell during the dormancy period. Soluble carbohydrate transport increases during dormancy release, and buds become strong sink organs at that phenological stage. Indeed, budburst is triggered by soluble carbohydrate metabolism (Bonhomme et al., 2010; Ito et al., 2012; Lacointe et al., 1993; Marafon et al., 2011; Marquat et al., 1999). In our study, it is possible to observe a trend in the increase of soluble carbohydrates from October to January (Fig. 3), which probably can continue once budbreak begins, although we evaluated the concentrations of soluble carbohydrates and starch before dormancy stage and during dormancy but not up to dormancy release.

The significant results observed for DW found in 2-year-old branches in October between the two levels of crop-load (data not shown), may be explained by their yield performance (Supplemental Table 1). During the growing season, there is competition among sink organs by assimilates (Flore and Layne, 1999); therefore, in a year of LCL it could be reasonably expected that there may be less contention among fruits and vegetative sinks, in contrast to a year with a high crop-load where competition would be greater. Further, according to results reported by Gagliardi et al. (2014) in 'Abbé Fétel' pear trees, branches 3 years old and older held the highest production, followed by 2 -year-old branches. The focus on these types of structures is because perennial branches form the skeleton (architecture) of the tree with minimal demand for assimilates for expected low growth (Naschitz et al., 2010), which increases with the age of the plant, as noted by Chalmers and Van den Ende (1975). In fact, our results showed that the 1-year-old branches obtained the highest values for the DW (active growth) (data not shown). Park (2011) and Monerri et al. (2011) agreed that during the growing season until harvest for persimmon (Park, 2011), and during postharvest for sweet orange (Monerri et al., 2011), the fruit 


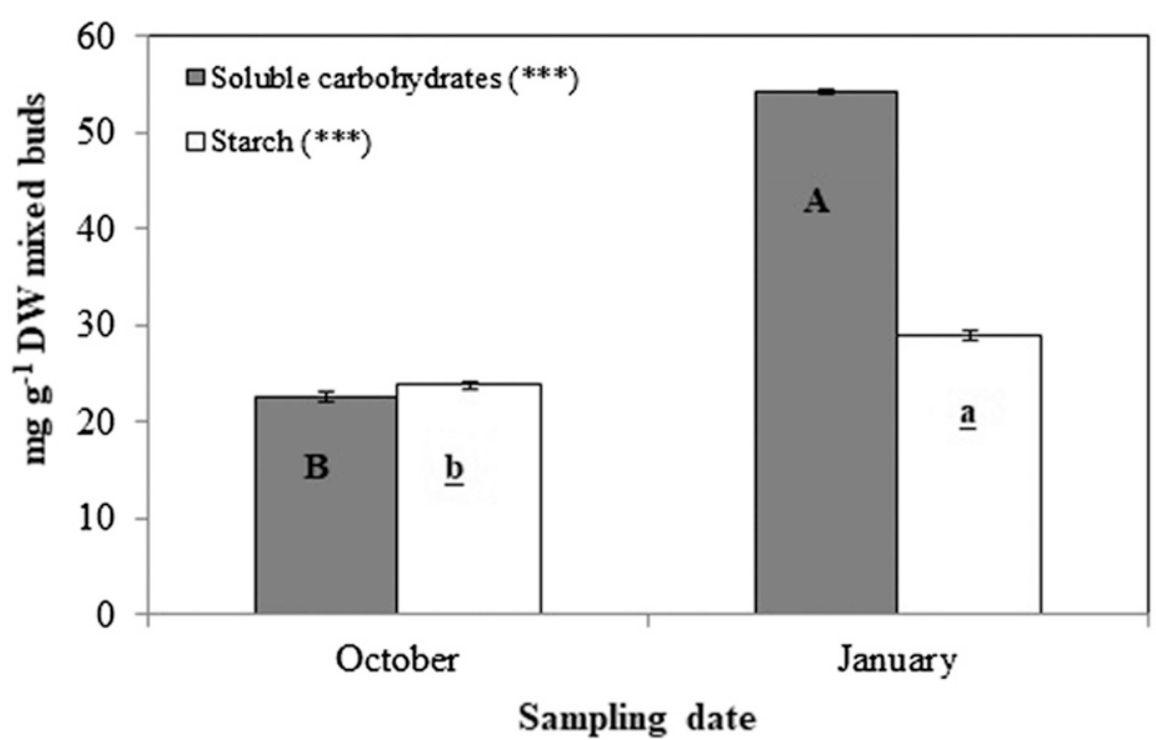

Fig. 3. Starch (white bars) and soluble carbohydrates (gray bars) concentrations $\left[\mathrm{mg}^{-g^{-1}}\right.$ dry weight (DW)] in mixed buds at different sampling dates. Values mean $\pm \operatorname{SE}(n=6)$. Upper case letters indicate significant difference in means among dates for soluble carbohydrates, and lower case letters for starch. *** indicates $P<0.001$; Student-Newman-Keuls test was used for mean comparisons.

A $\square$ Brindle-type shoots $\square$ 2-yrs-old $\square 3$-yrs-old $\square 4$-yrs-old $\square$ Short-old spurs
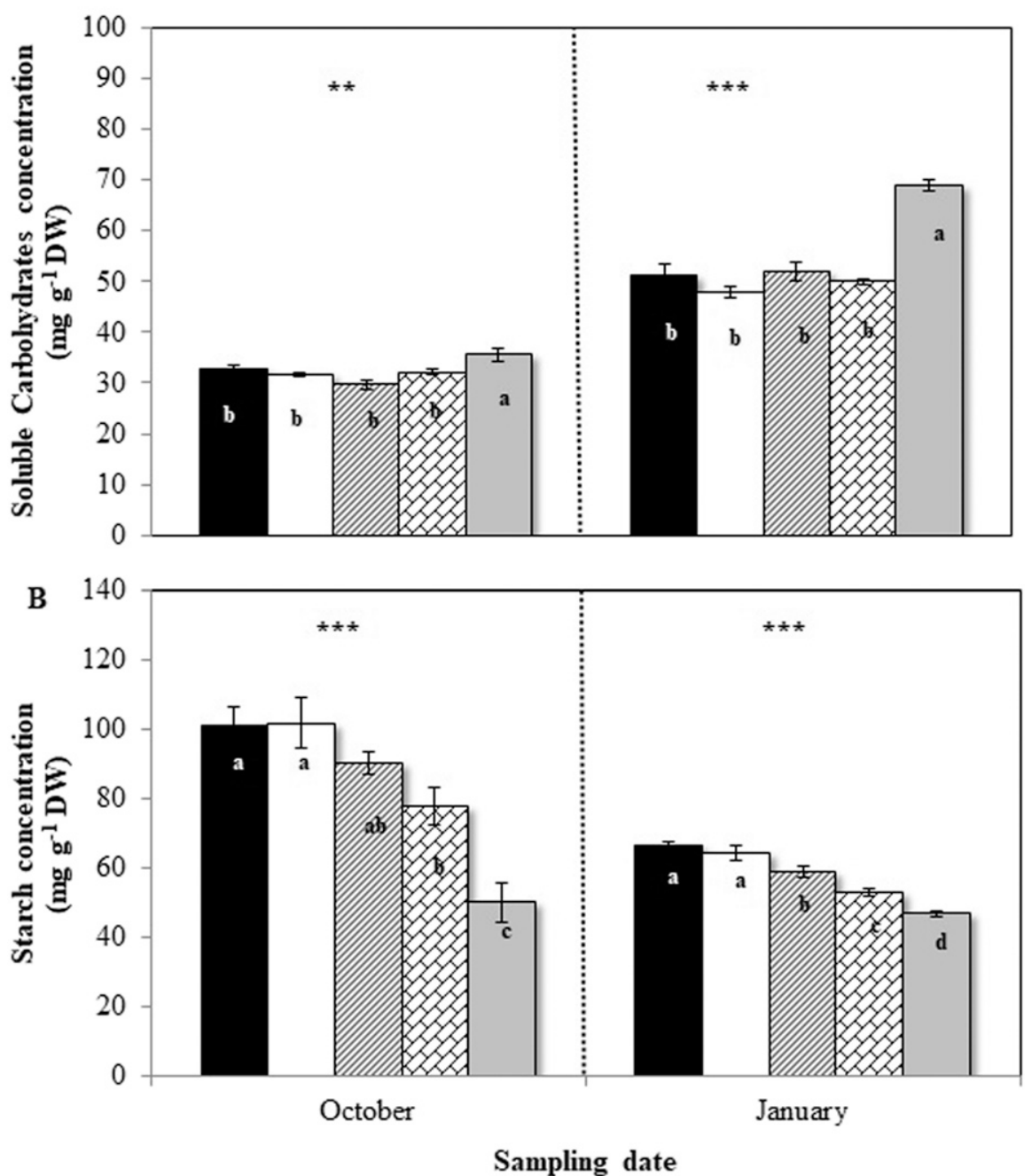

Fig. 4. Soluble carbohydrates (A) and starch concentrations (B) $\left[\mathrm{mg}^{-1} \mathrm{~g}^{-1}\right.$ dry weight (DW) of each organ] in different aboveground woody organs evaluated: 1-year-old branches, 2-year-old branches, 3-year-old branches, and 4+year-old branches, and short-old spur, for each of the two sampling dates. Values mean $\pm \operatorname{SE}(n=6)$. Lower case letters in the horizontal way indicate significant differences in means within each date of evaluation. **, *** indicate $P<0.01$ or 0.001 , respectively; Student-Newman-Keuls test was used for mean comparisons. detachment allowed the remaining organs to become stronger sinks.

\section{Starch and soluble carbohydrate analysis}

Starch and soluble carbohydrates in leaves. During the fruit development stage up to 107 to $115 \mathrm{~d}$ after full bloom, fruits also accumulated starch (Mesa et al., 2016), behaving as storage organs to support metabolic activities. Mesa et al. (2016) also pointed out a decrease of starch accumulation in leaves during the first $100 \mathrm{~d}$ after full bloom, perhaps attributable to the high demand for assimilates by fruit (as sinks). Several studies have explained in detail the process of starch degradation in leaves (Zeeman et al., 2004) using Arabidopsis as a model (Smith et al., 2005; Streb and Zeeman, 2012; Zeeman et al., 2007), but little information is available about this process during the endodormancy stage in nonphotosynthetic organs.

When the fruits reach their maturation on the tree, they are no longer considered sinks for assimilates because of the onset of starch degradation (Mesa et al., 2016). The hydrolysis of starch is correlated with a rise in soluble sugars content, an indicator of the incipient fruit maturity stage (Berüter, 2004; Mesa et al., 2016). This behavior is in contrast to other organs, such as shoots and roots (depending on their sink strength), as they require assimilates to accumulate reserves during fall before the tree enters into the dormancy period. This experiment showed the importance of leaf retention after harvest; leaves sampled in October showed a significantly higher amount of soluble carbohydrates with respect to leaves sampled at natural leaf fall (late November, Table 4).

Even if leaves entered in a senescence period as confirmed by their weight loss (Supplemental Fig. 1, Table 3) and \% WC decrease in late November (Table 3), they still presented a significant concentration of soluble carbohydrates (15.6 mg Glc/g DW, Table 4). The occurrence of an adverse climate event or damage by diseases or pests would cause a source-sink imbalance (even in fall), due to the decrease of active photosynthetic foliage (Flore and Layne, 1999). McCamant (1988), cited by Loescher et al. (1990), noted that sweet cherry trees defoliated in August have the lowest amount of starch in all tissues compared with trees defoliated at later dates. Hudina and Stampar (2002) studied the effect of the reduction of LA on the quality of pear fruits cv. Williams during their development and concluded that a $30 \%$ reduction in LA induced lower soluble solids and sugars in fruits because of a decrease in production of assimilates. Other research on 'Hayward' kiwifruit reports that a $75 \%$ reduction of foliage at $5 \mathrm{~d}$ after full bloom decreases the rate of starch accumulation in summer on current shoots and trunk bark but does not affect the starch concentrations in roots (Cruz-Castillo et al., 2010). Kwack et al. (2014), unlike the other results reported on defoliation treatment, observed an increase of starch concentrations in roots of kiwifruit cv. Goldrush in October, 
Table 5. Soluble carbohydrates concentration [mg Glucose (Glc)/g dry weight (DW)] in different types of branches: 1-year-old branches, 2-year-old branches, 3-year-old branches, 4+-year-old branches, and short-old spur.

\begin{tabular}{lccccccc}
\hline & \multicolumn{7}{c}{ Soluble carbohydrates concn (mg Glc/g DW) } \\
\cline { 2 - 8 } Organs & \multicolumn{2}{c}{ October } & \multicolumn{7}{c}{ January } & Significance & $\Delta$ (January-October) & \% Increase \\
\hline Wood & & & & & & & \\
1-year & 32.7 & b & 51.1 & a & $* * *$ & 18.4 & 56.3 \\
2-year & 31.7 & b & 48.0 & a & $* * *$ & 16.3 & 51.4 \\
3-year & 29.7 & b & 52.0 & a & $* * *$ & 22.3 & 75.1 \\
4-year & 32.1 & b & 49.9 & a & $* * *$ & 17.8 & 55.5 \\
Spurs & 35.6 & b & 68.9 & a & $* * *$ & 33.3 & 93.5 \\
\hline
\end{tabular}

Values are means of six replicates. Lower case letters along rows indicate significant difference in means between sampling dates (horizontally). ${ }^{* * *}$ indicates significance at $P<0.001$; Student-Newman-Keuls test was used for mean comparisons.

Table 6. Starch concentration [mg Glucose (Glc)/g dry weight (DW)] in different types of branches: 1-year old branches, 2-year-old branches, 3-year-old branches, 4+-year-old branches, and short-old spur.

\begin{tabular}{|c|c|c|c|c|c|c|c|}
\hline \multirow{3}{*}{$\frac{\text { Organs }}{\text { Wood }}$} & \multicolumn{7}{|c|}{ Starch concn (mg Glc/g DW) } \\
\hline & \multicolumn{2}{|c|}{ October } & \multicolumn{2}{|c|}{ January } & \multirow{3}{*}{$\begin{array}{c}\text { Significance } \\
\qquad * * *\end{array}$} & \multirow{3}{*}{$\begin{array}{c}\Delta(\text { January-October }) \\
34.7\end{array}$} & \multirow{3}{*}{$\begin{array}{c}\text { \% Decrease } \\
34.2\end{array}$} \\
\hline & & & & & & & \\
\hline 1-year & 101.4 & $\mathrm{a}$ & 66.7 & $\mathrm{~b}$ & & & \\
\hline 2-year & 102.0 & $\mathrm{a}$ & 64.3 & $\mathrm{~b}$ & $* * *$ & 37.7 & 36.9 \\
\hline 3 -year & 90.4 & $\mathrm{a}$ & 59.0 & $\mathrm{~b}$ & $* * *$ & 31.4 & 34.7 \\
\hline 4-year & 78.0 & $\mathrm{a}$ & 53.0 & b & $* * *$ & 25.0 & 32.0 \\
\hline Spurs & 50.2 & & 46.9 & & NS & 3.3 & 6.5 \\
\hline
\end{tabular}

Values are means of six replicates. Lower case letters along rows indicate significant difference in means between sampling dates (horizontally). NS, ${ }^{* *}$ indicate no significance or significance at $P<0.001$, respectively; a Student-Newman-Keuls test was used for mean comparisons.

with a reduction of $75 \%$ and $100 \%$ LA between August and September. Moreover, the significant loss of LA on summer-pruned trees may lead to a reduction in the carbohydrate and nutrient element concentrations in the remaining tissues, ultimately limiting tree growth (Ikinci, 2014). Therefore, a defoliation treatment conducted between harvest and natural leaf fall could more intensely affect some downstream growth stages, causing impacts on crop phenology and fruit development (Tustin et al., 1997).

Naschitz et al. (2010) reported that high carbon demands induce soluble sugar synthesis, whereas low carbon demand enhances starch accumulation first in leaves and then in roots and woody tissues. Moreover, Monerri et al. (2011) observed that the levels of carbohydrates in the leaves of low crop-loaded trees are double those in the high crop-load trees. This appears to match our findings, in which LCL leaves registered $115.9 \%$ more starch concentration than in MCL 1 month after harvest (Fig. 2). However, similar results obtained by Wünsche et al. (2005) on 'Braeburn' apple trees showed no significant differences in starch concentration between two levels of cropping at the end of the season (natural leaf fall).

Starch and soluble carbohydrates of woody organs, roots, and mixed buds. Studies on other species are largely consistent with our findings. Primarily, the starch stored in woody tissues reaches its maximum level in October. This result appears initially in agreement with observations made in young walnut trees (Lacointe et al., 1993), in which a decrease of starch concentrations between postharvest and dormancy was mainly due to conversion to soluble sugars in the aerial organs and finest roots. It has been reported in previous works that starch accumulated in woody tissues is almost entirely hydrolyzed during the dor- mancy period for the further availability to new growth, budbreak, and fruit set of the following season (Table 6, Fig. 4). Short-old spurs showed the smallest decline in starch concentration in the transition between October and January (6.5\%; Table 6, Fig. 4), but the highest increase in soluble carbohydrates (Table 5, Fig. 4). According to Naschitz et al. (2010) and Goldschmidt and Golomb (1982), the carbohydrate reserves in the current-year shoots and roots can be used directly during the growing season. The starch found in the tree architecture (old wood) can be considered an available reserve to support and maintain the growth of other tree organs. This might explain a higher soluble carbohydrate concentration obtained in January in short-old spurs (Table 5, Fig. 4).

Regarding soluble carbohydrates in woody organs, a reverse pattern of behavior was observed clearly in aboveground organs and in fine roots. Indeed, in January (dormancy period) an increase in soluble carbohydrate concentration was observed, confirming a process of interconversion between starch and soluble sugars (Oliveira and Priestly, 1988; Tables 5 and 6, Supplemental Fig. 2, Fig. 4). Sauter (1988) reported that low temperatures induced starch conversion to soluble sugars to improve cold acclimation and support the transition to ectodormancy. This could be explained by mobilization of soluble sugars from storage organs (roots and branches) toward utilization sinks (such as mixed buds before budbreak) in accordance with Marafon et al. (2011). Their results showed responses to cold temperature treatments (natural conditions, continuous artificial chilling, alternating temperatures, and lack of chilling) during the winter period. Marafon et al. (2011) pointed out that the increase of soluble sugars in branches of 16- year-old Japanese pear trees cultivar Housui could be the result of low temperatures during the dormancy period. This tendency also was observed in our experiment, where sugar accumulation in buds was reported in January (Fig. 4, Table 5).

Regarding the root systems, unlike what the other studies have reported (Goldschmidt and Golomb, 1982; Monerri et al., 2011), our experiment showed great storage of starch both in coarse and fine roots (Supplemental Fig. 2). It would be expected that after the harvest of an LCL year ("year off"), a greater accumulation of reserves in roots would occur considering the roots as the most active organ, as it has been reported for other species (Goldschmidt and Golomb, 1982; Lopez et al., 2007; Monerri et al., 2011); however, this was not observed in this experiment (Supplemental Fig. 2). One reason that at least partially explains the contradictory results could be that a small subportion had been selected as a representative subsample of the whole root system for the quantification. Therefore, there is a possible risk (larger the risk the larger the organ) of obtaining a value not entirely representative of the whole organ (Lopez et al., 2013). Despite this differing outcome, it was observed that the coarse roots showed greater storage capacity than fine roots where the starch concentration was lower. This agreed with the results described by Regier et al. (2010) for poplar trees. Fine roots, also known as "feeder roots," are primarily essential for the absorption of water and mineral nutrients. Therefore, they are relatively short-lived and remain unaffected by the growing conditions of the season, as also observed by Monerri et al. (2011).

\section{Conclusions}

The results of this work confirm that in pear trees cv. Abbé Fétel, the interconversion between starch and soluble carbohydrates during the dormancy period was organspecific, as reported for mixed buds, woody organs, and roots. The level of crop-load during the season had a major influence on the concentrations of starch compared with soluble carbohydrates after harvest (October); however, during the dormancy period (January) these differences were diminished. Among the woody organs, short-old spurs obtained the highest increase in soluble carbohydrates during dormancy, whereas for starch concentration, a significant decrease was observed in young structures. This increase in soluble carbohydrate concentrations observed during dormancy explains the need for soluble sugars to support the metabolic process and budbreak in early spring. On the other hand, the importance of the retention of active LA for a longer period showed that leaves in late November continued to produce assimilates, which are transported to the "sinking" organs in that period. Depending on time and intensity, the defoliation practice can influence the concentrations of nonstructural carbohydrates, which ultimately could affect bud quality and fruit set development for the following season. Our data 
proved that a very heavy defoliation can reduce reserve in mixed buds and other organs.

\section{Literature Cited}

Abbott, D.L. 1970. The role of budscales in the morphogenesis and dormancy of the apple fruit bud, p. 65-81. In: L.C. Luckwill and C.V. Cutting (eds.). Physiology of tree crops. Academic Press, London.

Anderson, J.L., E.A. Richardson, and C.D. Kesner. 1986. Validation of chill unit and flower bud phenology models for "Montmorency" sour cherry. Acta Hort. 184:71-78.

Berüter, J. 2004. Carbohydrate metabolism in two apple genotypes that differ in malate accumulation. J. Plant Physiol. 161:1011-1029.

Bonhomme, M., M. Peuch, T. Ameglio, R. Rageau, A. Guilliot, M. Decourteix, G. Alves, S. Sakr, and A. Lacointe. 2010. Carbohydrate uptake from xylem vessels and its distribution among stem tissues and buds in walnut (Juglans regia L.). Tree Physiol. 30:89-102.

Cameron, S.H. 1923. Storage of starch in the pear and apricot. Amer. Soc. Hort. Sci. 20:98-100.

Chalmers, D.J. and B. Van den Ende. 1975. Productivity of peach trees: Factors affecting dryweight distribution during tree growth. Ann. Bot. 39:423-432.

Cruz-Castillo, J.G., D.J. Woolley, and F. Famiani. 2010. Effects of defoliation on fruit growth, carbohydrate reserves and subsequent flowering of "Hayward" kiwifruit vines. Scientia Hort. 125:579-583.

Flore, J.A. and D.R. Layne. 1999. Photoassimilate production and distribution in cherry. HortScience 34:1015-1019.

Faust, M. 1989. Physiology of temperate zone fruit trees. John Wiley, New York, NY.

Gagliardi, F., S. Serra, V. Ancarani, D. Bucci, L. Piccinini, M. Noferini, S. Musacchi, and G. Costa. 2014. Preliminary results on Cv. "Abbé Fétel" productivity and fruit quality in relation to tree architecture. Acta Hort. 1058:151-158.

Goldschmidt, E.E. and A. Golomb. 1982. The carbohydrate balance of alternate-bearing citrus trees and the significance of reserves for flowering and fruiting. J. Amer. Soc. Hort. Sci. 107:206-208.

Grochowska, M.J. 1973. Comparative studies on physiological and morphological features of bearing and non-bearing spurs of the apple tree. I. Changes in starch content during growth. J. Hort. Sci. 48:347-356.

Hansen, P. 1967. ${ }^{14} \mathrm{C}$-Studies on apple trees III. The influence of season on storage and mobilization of labelled compounds. Physiol. Plant. 20:1103-1111.

Hansen, P. 1971. ${ }^{14} \mathrm{C}$-Studies on apple trees. VII. The early seasonal growth in leaves, flowers and shoots as dependent upon current photosynthates and existing reserves. Physiol. Plant. 25:469-473.

Hansen, P. 1973. The effect of cropping on the growth and uptake of nutrients by apple trees at different levels of nitrogen, potassium, magnesium and phosphorus. Acta Agr. Scand. 23:87-92.

Hansen, P. 1982. The effect of virus on yield components and fruit quality in three apple cultivars. Tidsskrift for Planteavl 86:55-63.

Hansen, P. and S. Stoyanov. 1972. Frugtudtynding II. Den nødvendige bladmængde til forsyning af frugten hos forskellige æblesorter (Fruit thinning II. Leaf areas and assimilate consumption in fruits of different cultivars of apple). Tidsskrift for Planteavl 646:646-652.
Ho, L.C. 1988. Metabolism and compartmentation of imported sugars in sink organs in relation to sink strength. Annu. Rev. Plant Physiol. Plant Mol. Biol. 39:355-378.

Hudina, M. and F. Stampar. 2002. Influence of leaf area on the sugar and organic acids content in pear (Pyrus communis) fruits cultivar Williams. Acta Hort. 596:749-752.

Ikinci, A. 2014. Influence of pre- and postharvest summer pruning on the growth, yield, fruit quality, and carbohydrate content of early season peach cultivars. Sci. World J. 2014:1-8.

Ito, A., D. Sakamoto, and T. Moriguchi. 2012. Carbohydrate metabolism and its possible roles in endodormancy transition in Japanese pear. Scientia Hort. 144:187-194.

Keller, J.D. and W.H. Loescher. 1989. Nonstructural carbohydrate partitioning in perennial parts of sweet cherry. J. Amer. Soc. Hort. Sci. 114:969-975.

Kozlowski, T.T. 1992. Carbohydrate sources and sinks in woody plants. Bot. Rev. 58:107-222.

Kwack, Y.B., H.L. Kim, W.B. Chae, S.H. Kim, Y.B. Lee, and J.G. Kim. 2014. Carbohydrate reserves of non-fruiting young kiwifruit vines as affected by early artificial defoliation. Hort. Environ. Biotechnol. 55:462-470.

Lacointe, A., A. Kajji, F.A. Daudet, P. Archer, J.S Frossard, B. Saint-Joanis, and M. Vandame. 1993. Mobilization of carbon reserves in young walnut trees. Acta Bot. Gallica 140:435-441.

Lloyd, J. and D. Firth. 1990. Effect of defoliation time in depth of dormancy and bloom time for low chill peaches. HortScience 25:1575-1578.

Loescher, W.H., T. McCamant, and J.D. Keller. 1990. Carbohydrate reserves, translocation, and storage in woody plant roots. HortScience $25: 274-281$

Lopez, G., J. Girona, and J. Marsal. 2007. Response of winter root starch concentration to severe water stress and fruit load and its subsequent effects on early peach fruit development. Tree Physiol. 27(11):1619-1626.

Lopez, G., M.H. Behboudian, J. Girona, and J. Marsal. 2013. Responses of "Conference" pear to deficit irrigation: Water relations, leaf discrimination against ${ }^{13} \mathrm{CO}_{2}$, tree starch content, growth, and recovery after rewatering. J. Plant Growth Regul. 32:273-280.

Marafon, A.C., I. Citadin, L. do Amarante, F.G. Herter, and F.J. Hawerroth. 2011. Chilling privation during dormancy period and carbohydrate mobilization in Japanese pear trees. Sci. Agr. 68:462-468.

Marquat, C., M. Vandamme, M. Gendraud, and G. Pétel. 1999. Dormancy in vegetative buds of peach: Relation between carbohydrate absorption potentials and carbohydrate concentration in the bud during dormancy and its release. Scientia Hort. 79:151-162.

McCamant, T. 1988. Utilization and transport of storage carbohydrate in sweet cherry. MS Thesis, Washington State Univ., Pullman, WA.

Mesa, K., S. Serra, A. Masia, F. Gagliardi, D. Bucci, and S. Musacchi. 2016. Seasonal trends of starch and soluble carbohydrates in fruits and leaves of "Abbé Fétel" pear trees and their relationship to fruit quality parameters. Scientia Hort. 211:60-69.

Monerri, C., A. Fortunato-Almeida, R.V. Molina, S.G. Nebauer, A. García-Luis, and J.K. Guardiola. 2011. Relation of carbohydrate reserves with the forthcoming crop, flower formation and photosynthetic rate, in the alternate bearing "Salustiana" sweet orange (Citrus sinensis L.). Scientia Hort. 129:71-78.
Musacchi, S. 2011. Training system and management for a high density orchard of 'Abbé Fétel'. Acta Hort. 909:225-240.

Naschitz, S., A. Naor, S. Genish, S. Wolf, and E.E. Goldschmidt. 2010. Internal management of non-structural carbohydrate resources in apple leaves and branch wood under a broad range of sink and source manipulations. Tree Physiol. 30:715-727.

Nzima, N.D.S., G.C. Martin, and C. Nishijima. 1997. Leaf development, dry matter accumulation, and distribution within branches of alternate-bearing "Kerman" pistachio trees. J. Amer. Soc. Hort. Sci. 122:31-37.

Oliveira, C.M. and C.A. Priestley. 1988. Carbohydrate reserves in deciduous fruit trees. Hort. Rev. 10:403-430.

Palmer, J.W. 1988. Annual dry matter production and partitioning over the first 5 year of a bed system of Crispin/M.27 apples trees at four spacing. J. Appl. Ecol. 25:569-578.

Palmer, J.W. 1992. Effects of varying crop load on photosynthesis, dry matter production and partitioning of Crispin/M.27 apples trees. Tree Physiol. 11:19-33.

Palmer, J.W. 1999. Light, canopies, fruit and dollars. The Compact Fruit Tree. 32:119-122.

Park, S.J. 2011. Dry weight and carbohydrate distribution in different tree parts as affected by various fruit-loads of young persimmon and their effect on new growth in the next season. Scientia Hort. 130:732-736.

R Core Team. 2017. R: A Language and Environment for Statistical Computing. <https:// www.R-project.org/>.

Regier, N., S. Streb, S.C. Zeeman, and B. Frey. 2010. Seasonal changes in starch and sugar content of poplar (Populus deltoides $\times$ nigra $\mathrm{cv}$. Dorskamp) and the impact of stem girdling on carbohydrate allocation to roots. Tree Physiol. 30:979-987.

Richardson, E.A., S.D. Seeley, and D.R. Walter. 1974. A model for estimating the completion of rest for 'Redhaven' and 'Elberta' peach trees. HortScience 9:331-332.

Robinson, T.L. and A.N. Lakso. 1991. Bases of yield and production efficiency in apple orchard systems. J. Amer. Soc. Hort. Sci. 116:188-194.

Roe, J. 1955. The determination of sugar in blood and spinal fluid with anthrone reagent. J. Biol. Chem. 212:335-343.

Rom, C.R. 1991. Light thresholds for apple tree canopy growth and development. HortScience 26:462-470.

Sansavini, S., V. Ancarani, and D. Neri. 2008. Overview of intensive pear culture: Planting density, rootstocks, orchard management, soilwater relations, and fruit quality. Acta Hort. 800:35-50.

Sauter, J. 1988. Temperature induced changes in starch and sugars in the stem of "Populus $x$ Canadensis robusta". J. Plant Physiol. 132:608-612.

Scholefield, P.B., M. Sedgley, and D.M. Alexander. 1985. Carbohydrate cycling in relation to shoot growth, floral initiation and development and yield in the avocado. Sci. Agr. 25:99-110.

Seager, N.G. and R.M. Haslemore. 1993. Rapid estimation of fruit starch and soluble sugar concentrations in kiwifruit. HortScience 28:948-950.

Silver, W.L. and R.K. Miya. 2001. Global patterns in root decomposition: Comparisons of climate and litter quality effects. Oecologia 129(3):407-419. 
Smith, A.M., S.C. Zeeman, and S.M. Smith. 2005. Starch degradation. Annu. Rev. Plant Biol. 56:73-98.

Smith, A.M. and S.C. Zeeman. 2006. Quantification of starch in plant tissues. Nat. Protoc. 1:1342-1345.

Streb, S. and S.C. Zeeman. 2012. Starch metabolism in Arabidopsis. Arabidopsis Book 10:e0160.

Titus, J.S. and S. Kang. 1982. Nitrogen metabolism, translocations, and recycling in apple trees. Hort. Rev. 4:204-246.

Tustin, D.S., C. Stanley, and H.M. Adams. 1997. Physiological and phenological response of apple trees to artificial reduction of the growth period from harvest to leaf fall. Acta Hort. 451:383-392.

Weinberger, J.H. 1950. Chilling requirements of peach varieties. Proc. J. Amer. Soc. Hort. Sci. 56:122-128.
Whiley, A.W., T.S. Rasmussen, J.B. Saranah, and B.N. Wolstenholme. 1996a. Delayed harvest effects on yield, fruit size and starch cycling in avocado (Persea americana Mill.) in subtropical environments. I. The early-maturing cv. Fuerte. Sci. Hort. 66:23-34.

Whiley, A.W., T.S. Rasmussen, J.B. Saranah, and B.N. Wolstenholme. 1996b. Delayed harvest effects on yield, fruit size and starch cycling in avocado (Persea americana Mill.) in subtropical environments. II. The latematuring cv. Hass. Sci. Hort. 66:35-49.

Wünsche, J.N., A.N. Lakso, T.L. Robinson, F. Lenz, and S.S. Denning. 1996. The bases of productivity in apple production systems: The role of light interception by different shoot types. J. Amer. Soc. Hort. Sci. 121:886-893.

Wünsche, J.N. and A.N. Lakso. 2000. The relationship between leaf area and light interception by spur and extension shoot leaves and apple orchard productivity. HortScience 35:1202-1206.

Wünsche, J.N., D.H. Greer, W.A. Laing, and J.W. Palmer. 2005. Physiological and biochemical leaf and tree responses to crop load in apple. Tree Physiol. 25(10):1253-1263.

Zeeman, S.C., S.M. Smith, and A.M. Smith. 2004 The breakdown of starch in leaves. New Phytol. 163:247-261

Zeeman, S.C., S.M. Smith, and A.M. Smith. 2007. The diurnal metabolism of leaf starch. Biochem. J. 401:13-28.

Zhang, X. and W. Wang. 2015. The decomposition of fine and coarse roots: Their global patterns and controlling factors. Sci. Rep. 5:9940.

Zimmerman, R.H., M. Faust, and A.W. Shreve. 1970. Glucose metabolism of various tissues of pear buds. Plant Physiol. 46:839-841. 
Supplemental Table 1. Yield performance of 'Abbé Fétel' pear trees evaluated in 2012, with two levels of crop-load.

\begin{tabular}{lcccc}
\hline & TSCA average $\left(\mathrm{cm}^{2}\right)$ & Fruit (no./tree) & Yield (kg/tree) & Average fruit weight $(\mathrm{g})$ \\
\hline Crop-load 2012 & & & & \\
LCL & 59.0 & $10 \mathrm{~b}$ & $2.4 \mathrm{~b}$ & 249 \\
MCL & 61.3 & $25 \mathrm{a}$ & $6.3 \mathrm{a}$ & 252 \\
Significance & $\mathrm{NS}$ & $* * *$ & $* * *$ & NS \\
\hline
\end{tabular}

Lower case letters along columns indicate significant differences. NS, ${ }^{*}, * *, * * *$ indicate no significance or significance at $P<0.05,0.01$, or 0.001 , respectively; a Student-Newman-Keuls (SNK) test was used for mean comparisons. Values are mean of six replicates.

Supplemental Table 2. Dry weight of woody organs (above and underground) and mixed buds per pear trees cv. 'Abbé Fétel' evaluated at different dates.

\begin{tabular}{|c|c|c|c|c|c|c|}
\hline \multirow[b]{2}{*}{ Organs } & \multirow[b]{2}{*}{ unit } & \multicolumn{5}{|c|}{ Dry weight } \\
\hline & & October & & January & & Significance \\
\hline \multicolumn{7}{|l|}{ Wood } \\
\hline 1-year & $\mathrm{g}$ & 255.1 & & 263.6 & & NS \\
\hline 2-year & $\mathrm{g}$ & 177.3 & & 215.6 & & NS \\
\hline 3 -year & $\mathrm{g}$ & 188.2 & & 149.5 & & NS \\
\hline 4-year & $\mathrm{g}$ & $1,798.8$ & & $1,619.8$ & & NS \\
\hline Spurs & $\mathrm{g}$ & 152.9 & & 99.6 & & NS \\
\hline Trunk & $\mathrm{g}$ & $4,077.2$ & & $4,568.6$ & & NS \\
\hline Mixed buds & $\mathrm{g}$ & 20.0 & & 26.6 & & NS \\
\hline \multicolumn{7}{|l|}{ Roots } \\
\hline Coarse $(>2 \mathrm{~mm})$ & $\mathrm{g}$ & 988.8 & $\mathrm{a}$ & 709.5 & $\mathrm{~b}$ & * \\
\hline Fine $(<2 \mathrm{~mm})$ & $\mathrm{g}$ & 60.4 & & 49.9 & & NS \\
\hline
\end{tabular}

Values are means of six replicates. Lower case letters indicate significant differences among means along rows. Ns, ${ }^{*}, * *, * * *$ indicate no significance or significance at $P<0.05,0.01$, or 0.001 , respectively; a Student-Newman-Keuls (SNK) test was used for mean comparisons. 
Supplemental Table 3. Starch concentrations $\left(\mathrm{mg} \cdot \mathrm{g}^{-1}\right.$ DW) in different woody organs (above and underground) and mixed buds of pear trees cv. Abbé Fétel evaluated after harvest 2012 (October) according to the level of crop load: medium crop load (MCL) and low crop load (LCL).

\begin{tabular}{lrrr}
\hline & \multicolumn{3}{c}{ Starch } \\
\cline { 2 - 4 } Organs/Crop load & \multicolumn{3}{c}{ (mg starch/g DW) } \\
\cline { 2 - 4 } & MCL & \multicolumn{1}{c}{ LCL } & Significance \\
\hline Wood & & & \\
1-year & 94.6 & 108.2 & NS \\
2-year & 112.2 & 91.7 & NS \\
3-year & 95.6 & 85.1 & NS \\
4-year & 87.7 & 68.3 & NS \\
$\quad$ Spurs & 62.6 a & $37.8 \mathrm{~b}$ & $* *$ \\
Mixed buds & 22.9 & 24.6 & NS \\
Roots & & & \\
Coarse $(>2 \mathrm{~mm})$ & 44.2 & 40.1 & NS \\
Fine $(<2 \mathrm{~mm})$ & 17.3 & 15.6 & NS \\
\hline
\end{tabular}

Lower case letters indicate significant differences along rows. Ns, $*, * *, * * *$ indicate no significance or significance at $P<0.05,0.01$, or 0.001 , respectively; a Student-Newman-Keuls (SNK) test was used for mean comparisons. Values are mean of six replicates.

Supplemental Table 4. Soluble carbohydrate concentrations (mg. $\mathrm{g}^{-1}$ DW) in different woody organs (above and underground) and mixed buds of pear trees cv. Abbé Fétel evaluated after harvest 2012 (October) according to the level of crop load: medium crop load (MCL) and low crop load (LCL).

\begin{tabular}{|c|c|c|c|}
\hline \multirow[b]{3}{*}{ Organs/Crop load } & \multirow{2}{*}{\multicolumn{3}{|c|}{$\begin{array}{l}\text { Soluble Carbohydrates } \\
\text { (mg glucose/g DW) }\end{array}$}} \\
\hline & & & \\
\hline & $\overline{\mathrm{MCL}}$ & LCL & Significance \\
\hline \multicolumn{4}{|l|}{$\overline{\text { Wood }}$} \\
\hline 1 -year & 34.4 & a $31.1 \mathrm{l}$ & $*$ \\
\hline 2 -year & 31.9 & 31.6 & NS \\
\hline 3 -year & 31.8 & a 27.61 & * \\
\hline 4 -year & 32.1 & 32.1 & NS \\
\hline Spurs & 33.8 & 37.3 & NS \\
\hline Mixed buds & 23.4 & 21.9 & NS \\
\hline \multicolumn{4}{|l|}{ Roots } \\
\hline Coarse $(>2 \mathrm{~mm})$ & 50.5 & 50.1 & NS \\
\hline Fine $(<2 \mathrm{~mm})$ & 35.0 & 34.4 & NS \\
\hline
\end{tabular}

Lower case letters indicate significant differences along rows. ns, $*, * *, * * *$ indicate no significance or significance at $P<0.05,0.01$, or 0.001 , respectively; a Student-Newman-Keuls (SNK) test was used for mean comparisons. Values are mean of six replicates.



\section{Treatment}

Supplemental Fig. 1. Interaction between crop-load (MCL and LCL) and sampling date (after harvest and natural leaf fall) for average leaf weight (mg) per tree. Mean values $\pm \mathrm{SE}$ (black bars). Lower case letters indicate significant differences. ns, ${ }^{*}, * *, * * *$ indicate no significance and significance at $P<0.05$, 0.01 , or 0.001 , respectively; Student-Newman-Keuls test was used for mean comparisons. 

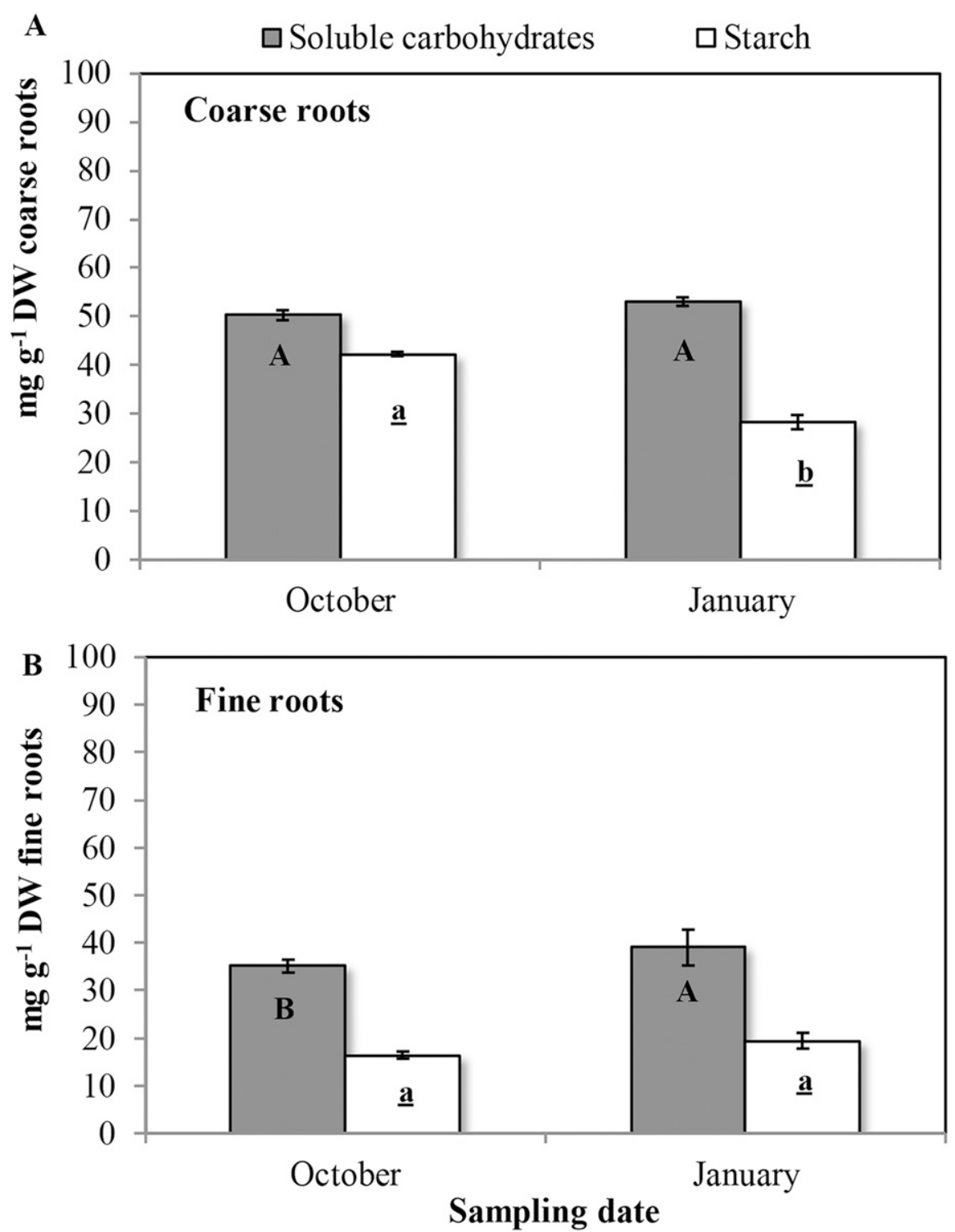

Supplemental Fig. 2. Starch (white bars) and soluble carbohydrate (gray bars) concentrations ( $\mathrm{mg} \cdot \mathrm{g}^{-1} \mathrm{DW}$ ) in coarse (A) and fine roots $(\mathbf{B})$, for each of the two-sample date during the trial. Values means $\pm \mathrm{SE}(n=6)$. Capital letters indicate significant differences in means among dates for soluble carbohydrates, and lower case and underlined letters for starch. ns, ${ }^{*}, * *, * * *$ indicate no significance or significance at $P<0.05$, 0.01, or 0.001, respectively; Student-Newman-Keuls test was used for mean comparisons. 